\title{
Tapping the Economic Potential of Chickpea in Sub-Saharan Africa
}

\author{
Asnake Fikre ${ }^{1}{ }^{(}$, Haile Desmae $^{2, *}$ and Seid Ahmed ${ }^{3}$ \\ 1 Legume Research Program, Ethiopian Institute of Agricultural Research (EIAR), Crops Research Directorate, \\ Addis Ababa 1000, Ethiopia; Fikreasnake@yahoo.com \\ 2 International Crops Research Institute for Semi-Arid Tropics (ICRISAT), Bamako BP 320, Mali \\ 3 International Center for Agricultural Research in the Dry Areas (ICARDA), 11025 Rabat, Morocco; \\ S.A.Kemal@cgiar.org \\ * Correspondence: h.desmae@cgiar.org; Tel.: +223-71178098
}

Received: 16 October 2020; Accepted: 31 October 2020; Published: 4 November 2020

\begin{abstract}
Chickpea is a nutrition-rich, cropping-system friendly, climate-resilient, and low-cost production crop. It has large economic potential in the sub-Saharan Africa (SSA) region, where it currently accounts for only approximately half a million hectares of the approximately 12 million hectares of total chickpea production land worldwide. This review highlights the opportunities for promoting chickpea production and marketing to tap the vast economic potential in SSA. The region can potentially produce chickpea on approximately 10 million hectares, possibly doubling the global production, and the region could become one of the highest consumption geographies of this healthy crop. Chickpea could easily be integrated into existing cropping systems including rice-fallows and cereal monocropping systems. Successful cases studies of the crop in the region are highlighted. The region could tap into the potential at scale through intervention in the agricultural policy environment and development and promotion of improved chickpea production technologies supported by well-organized extension services and sustainable seed systems. These interventions could be complemented with value addition and product quality improvementsÍ for SSA chickpea to benefit from high-value markets.
\end{abstract}

Keywords: chickpea; SSA; economic potential; market; farmer preference; intensification; breeding; seed systems

\section{Introduction}

Agriculture remains Africa's biggest opportunity to drive economic growth and meet food demand for its growing population which faces persistent problems of food and nutrition insecurity [1]. The continent is a net importer of agricultural products, where it spends approximately USD $\$ 60$ billion on food imports annually to fill the deficit [2]. The sub-Saharan Africa (SSA) region accounts for at least two-thirds of the continental landmass bounded by the west-east extended Sahel depression from northern Africa countries. The population of SSA is estimated to be approximately 1.09 billion people in 2020 and is projected to reach about 2.12 billion people or almost $22 \%$ of the world's total by 2050 [3]. Agriculture accounts for approximately 15\% of the region's GDP with the lowest contribution of $1.9 \%$ observed for Botswana and the highest, $57.4 \%$, for Sierra Leone [3], and it is the main source of livelihood for poor people. The total agricultural production value is dominated by the crop sector, where it accounts for almost $85 \%$ of total production value, ranging from $53 \%$ in Southern Africa to more than $90 \%$ in Western Africa [3]. Agriculture also has an important contribution to the export sector with 30\% for East Africa, 10\% for Southern Africa, and 10\% for West Africa in 2019 [4], and they are dominantly bulk agricultural exports rather than processed products. 
The SSA region has a vast potential for agricultural development. The diverse climate and rainfall patterns as well as clay-to-sandy soils provide a wider scope for year-round adaptation, cultivation, and commercialization for most of the globally important cereal and legume crops. Although an increase in agricultural production has been observed over the years, it has not kept up with the pace of population growth in the region [5]. Progress toward achieving global and continental commitments, such as the Millennium Development Goal 1 (MDG1) and the Comprehensive Africa Agriculture Development Programme (CAADP), has generally been slow. For example, few SSA countries have invested in the agriculture sector reaching the $10 \%$ budget share set by CAADP and have achieved major agricultural transformation with a growth rate exceeding the CAADP target of $6 \%$ [6]. Enormous agricultural development potential remains to be exploited through improved technical and institutional capacity, policy, and the investment environment in the agricultural sector. The agricultural sector is still dominated by subsistence smallholder farming with low productivity and high vulnerability to natural and human-made risks including climate change. Water scarcity is increasingly becoming a major limitation for agricultural production and food security [7]. For the SSA region to achieve real livelihood transformation, subsistence farming needs to move to market-oriented farming [6]. The region has to make a significant investments in the resilience of farming systems and protection of natural resources [5] for households to mitigate and adapt to shocks. Current production and productivity levels need to be improved through sustainable intensification to enhance resilience and agricultural transformation. The 50 years African grand development milestones by 2063 stipulate (AGENDA 2063), among others, that advanced agricultural technologies and options provide the creation of drought- and pest-resistant varieties, shorter harvesting cycle cultivars, several crops per season, and cost-saving techniques such as free nitrogen fixation [8]. Chickpea (Cicer arietinum L.), a highly nutritious, climate-resilient, environmentally friendly, and nitrogen-fixing crop with huge market opportunities, could be one of the crops with strategic relevance for the agricultural sector transformation and improving food and nutrition security, soil health, economic returns, and income stability in SSA. This paper aimed to review and highlight opportunities for promoting chickpea production and marketing to tap the vast economic potential in SSA.

\section{Importance of Chickpea in Sub-Saharan Africa}

Chickpea is the second most important legume globally $[9,10]$. Historically, the geographic spread of chickpea started approximately 2000 years ago in the Mediterranean, Europe, the Indian sub-continent, and north-east Africa, and more recently in Mexico and Chile via post-Columbus introduction [11]. Archaeological evidence from Lalibela caves in Ethiopia dated seed samples over 2500 years old [12]. On top of this, the wild relative (C. cuneatum) of chickpea was found in Northern Ethiopia, suggesting chickpea originated in Ethiopia. However, with the current consensus, Ethiopia is considered as the secondary center of diversity for chickpea [13]. Despite this age in the region, chickpea seems to have a slow expansion history in SSA with few countries, including Eritrea, Ethiopia, Kenya, Malawi, Niger, South Sudan, Sudan, Togo, Uganda, Tanzania, and Zimbabwe, devoting significant area. In general, the chickpea area, production, and productivity trend in SSA since 1961 shows incremental increases (Figure 1) with an area of 188,000 hectares (ha) in 1961 increasing to 380,395 ha (>100\% increase) in 2018, while the production increased from 123,600 tonnes (t) to $637,681 \mathrm{t}$ in the same period [4] with the highest production of 711,092 $\mathrm{t}$ in 2015. Similarly, productivity increased from approximately $657 \mathrm{~kg} / \mathrm{ha}$ in 1961 to $1204 \mathrm{~kg} / \mathrm{ha}$ in 2018 . 


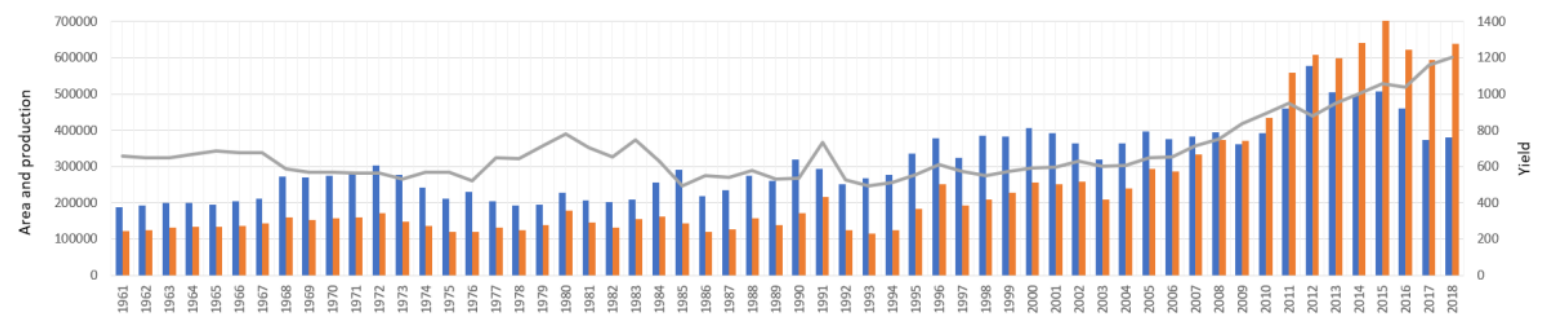

Figure 1. Chickpea area, production, and productivity trends in sub-Saharan Africa (SSA) from 1961-2018 [4].

In terms of the global area and production share, Africa accounts for less than $6 \%$ of the production, the SSA accounts for approximately $82.3 \%$ of the chickpea area and $88.6 \%$ of the production volume on the continent [14]. In terms of market share, the region makes less than USD $\$ 100$ million $(<9 \%)$ out of the approximately USD $\$ 1.1$ billion annual global revenue from the approximately 1.8 million tonnes of global chickpea transactions [15]. Several factors make chickpea a crop with high economic potential for the SSA region:

- Chickpea has a high potential for expansion and economic benefit;

- Chickpea is a suitable driver for sustainable intensification;

- Chickpea has a low production cost;

- Chickpea is adaptive to climatic shocks, particularly moisture and thermal stresses;

- Chickpea has diversified food, nutrition, feed uses, and health benefits;

- Chickpea has a high market value.

\subsection{Chickpea Has a High Potential for Expansion and Economic Benefit}

Several climatic and ecological analyses and predictions are pointing to the need for adaptive changes in crops or new species and shifts in cultural practices or enterprises $[16,17]$. The agricultural landscape is moving towards water deficit and thermal increase so that calamities could only be mitigated with the use of shock adaptive crops. With proper policy and technology support, chickpea has a huge potential in SSA to be a multibillion dollar transaction commodity. It could be a strategic commodity that greatly contributes to the commercialization of smallholder farmers and the generation of foreign exchange revenues $[15,18]$. The current agricultural landscapes of the semi-arid and arid tropics of SSA are suitable for the expansion of chickpea at scale. The high potential of mainstreaming chickpea in different cropping systems throughout the region could contribute to increased global production and a significant share of the market value. The productivity of chickpea in SSA can easily surpass $2 t / h a$, such that it will remain a profitable agricultural commodity. This economic benefit is being harnessed in some SSA countries. For instance, Ethiopia and Tanzania are producing chickpea at an export scale. In recent years, transformative progress has been made in the chickpea value chain in Ethiopia. Verkaart et al. [18] reported on the impressive progress and noted the following summary:

"Many studies detail constraints deemed responsible for the limited adoption of new technologies among smallholder farmers in sub-Saharan Africa. By contrast, here we study the conditions that led to the remarkably fast spread of improved chickpea varieties in Ethiopia. Within just seven years, the adoption rate rose from 30 to $80 \%$ of the farmers. A combination of factors explains the rapid uptake. Their attraction lay in superior returns and disease resistance. Chickpea was already an important crop for rural households in the studied districts, for both cash income and consumption. Good market access and easy accessibility of extension services advanced the adoption process. Thus, an attractive technology suitable for rural households in a conducive environment enabled adoption. 
Our findings prompt us to stress the importance of tailoring agricultural innovations to the realities and demands of rural households, and the need to design and deploy interventions on the basis of ex-ante knowledge on factors potentially determining their success or failure."

Fikre [19] pointed out that the shift toward chickpea in Ethiopia, from a simple precursor to a principal crop by itself, has resulted in a dramatic change over the last two decades as a result of the increasing socio-economic and climate-responsive role demonstrated by the crop. The market value of the produce was among the leading factors for considering chickpea among the priority crops for improving smallholder farmers' livelihoods in Ethiopia.

\subsection{Chickpea Is a Suitable Driver for Sustainable Intensification}

Sustainable intensification-producing more food from the same area of land while reducing the environmental impacts [20] — is an important strategy to eradicate poverty and hunger. In SSA, the cropping systems for staple crops, such as sorghum, maize, rice, wheat, and tef, are characterized by a dominantly mono-cropping system. Sub-Saharan African soils are exposed to a high depletion of nitrogen, potassium, and other nutrients due to the leaching and soil erosion as well as the continuous cropping of cereals without rotation with legumes. The low productivity consequence in the region comes partially from repeated cropping of the same crop. For instance, wheat mono-cropping in Ethiopia is not only an issue of productivity but a source of rust inoculums that spreads globally. It is important to promote the adoption of sustainable intensification practices among rural households to improve crop production in the SSA. Chickpea is versatile for cropping association with different cereals (e.g., tef, sorghum, maize, wheat, rice, millet) in diverse systems, viz., double cropping, relay cropping, rotational cropping, etc. [21,22]. Chickpea is not a heavy moisture feeder. In areas where double cropping per season is designed or short rain spells prevails, chickpea manages to survive its reproductive phase using the residual progressively depleting moisture $[21,23]$. The deep root system utilizes the untapped moisture resource by the previous crop, and the chickpea crop breaks and disrupts the circuit of regular pest and ameliorates soil fertility by natural nitrogen replenishment of the soil for use by cereals planted after. Through biological fixation of approximately $140 \mathrm{~kg} / \mathrm{ha}$ nitrogen [24], chickpea contributes to at least one-third of the $\mathrm{N}$ fertilizer needs of the following cereal crop. This natural fixation of nitrogen from the air can save up to $20 \mathrm{USD} / \mathrm{ha}$, which otherwise should be supplied by the application of chemical fertilizer. This, in turn, is also environmentally friendly and safe with almost zero pollution.

The integration of chickpea into cropping systems would contribute to increasing total production, mitigating crop failure, sustaining the systems, improving benefits, and optimizing resource use. The different cropping systems to which chickpea is an important component creates a cumulative intensification (CI). In Ethiopia, for example, bread wheat planted following rotation with legumes produced a higher grain yield with a yield advantage of $8-14 \%$ than the application of $41-46 \mathrm{~kg} / \mathrm{ha}$ $\mathrm{NP}_{2} \mathrm{O}_{5}$ [25]. Also, double cropping of wheat with chickpea provided the highest grain yield of $2.7 \mathrm{t} / \mathrm{ha}$ for the wheat variety and $2.6 \mathrm{t} / \mathrm{ha}$ for the chickpea variety in just one growing season (June-December). This combination demonstrated double-cropping rewards to a maximum land equivalent ratio of 1.99 , implying the yield and benefit maximization per unit area per season [21]. Similarly, research results proved the advantage of chickpea by tef rotational (1:3) production, where high productivity of both crops was sustainably realized [26]. In Malawi, chickpea is grown along with multiple crops, possibly as risk aversion [27]. In Tanzania, the Lake Zone catchment is planted to chickpea following rice and the retreat of Lake Victoria, and the crop is fully grown using the receding residual moisture [28]. The yield per unit area with superior cultivars of chickpea reaches up to $2.5 \mathrm{t} / \mathrm{ha}$ in addition to the principal rice crop from the same plot in a season. 
Chickpea is also a suitable crop for an irrigated production system. Multiple generations of chickpea up to six per year were reported by Fikre and Degefu [29] under field experimental conditions, which demonstrated the possibility to obtain high gains per unit area per unit time in production using irrigation during the dry season. Irrigation based production of chickpea enhances productivity as can be observed from Sudan with productivity of $>3 \mathrm{t} / \mathrm{ha}$ [14]. In Ethiopia, irrigated chickpea productivity is about $3.2 \mathrm{t} / \mathrm{ha}$ [30]. Moisture requirement assessment under Debre Zeit black soil condition of $\sim 50 \% \mathrm{RH}$ and $20^{\circ} \mathrm{C}$ mean daily Temperature (September-December) revealed a $37.2 \mathrm{~mm}, 114.4 \mathrm{~mm}, 205.2 \mathrm{~mm}$, and $79.8 \mathrm{~mm}$ net irrigation requirement of the crop during the seedling, vegetative, reproductive, and maturity stages, respectively. This indicates a total of $436.6 \mathrm{~mm}$ irrigation requirements of the crop for a single growing season [31].

\subsection{Chickpea Has a Low Production Cost}

The production cost of chickpea is at least $50 \%$ less than that of other field crops [32]. It has a deep root system reaching more than one meter [33], and these roots exploit the residual receding moisture while the canopy system above the ground keeps cool and moist conditions with a covered canopy sphere, which in combination enable the crop to make strategically less risky phenological responses for vegetative and reproductive development. The effect of weed species on chickpea in the late crop system is often low because biomass initiation is limited by low moisture and shading/smothering canopy effects of chickpea. Shiferaw et al. [22] reported a chickpea production cost of $\sim$ USD $\$ 60$ per quarter of a hectare, which makes the cost-benefit ratio approximately 1:2. Kassie et al. [34] forecasted a price change of approximately $10 \%$ per year for chickpea, which could change the rate of the cost-benefit ratio. Fikre [35] reported that income generated per hectare in Ethiopia ranged from USD $\$ 1500$ to USD $\$ 2000$, which was attributed to high prices and productivity gains of chickpea. Wondimu and Fikre [36] reported a production cost of $\sim$ USD $\$ 253.6$ per quarter of a hectare and $\sim$ USD $\$ 788$ benefit generated from grain produce indicating a 1:3 cost to benefit ratio. The ratio could be even a much higher at 1:5 if the product is marketed for the green pod. In all cases, the chickpea production cost is possibly among the smallest, particularly in a situation where it is produced during post the rainy season under residual moisture situation.

\subsection{Chickpea Is Adaptive to Climatic Shocks: Moisture and Thermal Stresses}

Chickpea can be considered an agriculturally resilient crop for SSA because it can be produced in moisture stress areas. In drought-driven shocks, nutrient-dense food deficit is often a challenge. In such a phenomenon, chickpea could be a choice to mitigate malnutrition for the most vulnerable groups-women and children. The deep root systems confer grain yield advantages during drought, particularly terminal moisture stress [37]. In Ethiopia, for example, chickpea and Lathyrus are the only resorts in cases of the cereal crops' failures due to the intermittent rainy season conditions. Recent scientific evidence has indicated that chickpea is not only adapted to moisture stress but it possesses the genetic means to be deployed in coping with thermal stresses $[10,38,39]$. The availability of sufficient variation in gene pool resources, particularly the desi types, for heat tolerance was reported [10]. According to the authors, a simple robust technique to screen for heat using staggered plantings was established. Thus far, the heat-tolerant breeding line ICCV 92944 has been released for cultivation in Myanmar as Yezin 6 [40], India as JG 14, Kenya as Chania Desi 2, and Bangladesh as BARI Chola 10 [10], and another variety, ICCV 09309, was identified in Ethiopia [38]. The line JG 14 is becoming popular for sowing under late-sown conditions (e.g., rice-fallows) in India giving $24-40 \%$ higher yields over the local check [10]. These attributes make chickpea even more relevant to the SSA region. 


\subsection{Chickpea Has Diversified Food, Nutrition, Feed Uses, and Health Benefits}

Chickpea can be put into diverse uses: food, feed, nutrition, market, homemade processing, health food [41]. It is a smallholder farmer and gender-friendly crop in that chickpea can be a backyard crop handled by women for home consumption (e.g., green pod, grain, leaves), medium-sized fields for market and home consumption or at the commercial scale for a wider market and agro-processing [32]. Chickpea plays an important role in human nutrition by providing approximately $20-24 \%$ protein, $4-10 \%$ fat, $52-71 \%$ carbohydrates, $10-23 \%$ fiber, essential amino acids (mainly, lysine, methionine, threonine, valine, isolucine and leucine), and a considerable amount of vitamins such as B1 and B2, ascorbic acid (vitamin C), and niacin [24]. Chickpea can be utilized in different preparations and different processing methods for home consumption, and the nutritional composition of the products vary (Table 1). Processing methods, such as dry roasting, dehulling, soaking, and germination and boiling, significantly affect the proximate compositions and functional properties [41]. Dehulling and germination increase the nutritional value, while the boiling method is best for high water and oil absorption capacity. Dehulling is also the best method to increase protein, fat, and energy values and the lower bulk density value in the formulation of complementary foods for children under two years of age [41], while boiling was found to be the best for reduction of antinutritional factors [42]. Chickpea is also becoming increasingly preferred as a natural health diet on the premises that it protects common cases of diabetic or allergy syndromes, which are becoming life-threatening common public health problems [43]. It is also particularly high in fiber. Studies have shown that people with type 1 diabetes who consume high-fiber diets have lower blood glucose levels, and for people with type 2 diabetes, higher fiber intake can improve and stabilize blood sugar, lipids, and insulin levels [44,45]. It has a low glycemic index, preventing blood sugar levels from rising too rapidly after a meal, and this makes it an especially good choice for people suffering from diabetes, insulin resistance, or hypoglycemia. In Ethiopia, Christian monastics (monks or nuns) residing in about 1500 Ethiopian monasteries, since 6 th $C$, principally depend on boiled or roasted chickpea grain consumption as part of their devoted spiritual life. There is no clinical evidence of this community having any health issue complications related to diabetics, blood pressure, allergies, unlike common people. With the increase in area and production, chickpea could spread its culinary influence in SSA through consumption, as it did in other parts of the world. Awareness creation and education of its nutritional benefit, value-added, and easy to use products and recipes would help increase consumption.

Table 1. Effect of processing methods on the proximate composition (\% in $\mathrm{db}$ ) and energy.

\begin{tabular}{ccccccc}
\hline \multirow{2}{*}{$\begin{array}{c}\text { Processing } \\
\text { Methods }\end{array}$} & Ash & Crude Protein & Crude Fiber & Crude Fat & Total CHO & $\begin{array}{c}\text { Energy } \\
\text { kcal/100 g }\end{array}$ \\
\cline { 2 - 7 } & & & & & & \\
& & & & & \\
Raw & $3.77 \pm 0.04^{\mathrm{a}}$ & $18.71 \pm 1.39^{\mathrm{c}}$ & $5.81 \pm 0.50^{\mathrm{a}}$ & $6.97 \pm 0.20^{\mathrm{c}}$ & $55.90 \pm 1.28^{\mathrm{d}, \mathrm{c}}$ & $361.13 \pm 2.66^{\mathrm{e}}$ \\
Dry roasting & $3.44 \pm 0.04^{\mathrm{e}}$ & $12.51 \pm 1.07^{\mathrm{e}}$ & $3.93 \pm 0.22^{\mathrm{d}}$ & $6.94 \pm 0.34^{\mathrm{c}}$ & $68.52 \pm 1.14^{\mathrm{a}}$ & $386.54 \pm 3.38^{\mathrm{b}}$ \\
Dehulling & $3.21 \pm 0.02^{\mathrm{f}}$ & $22.62 \pm 0.58^{\mathrm{a}}$ & $2.43 \pm 0.16^{\mathrm{e}}$ & $8.48 \pm 0.63^{\mathrm{a}}$ & $56.52 \pm 1.34^{\mathrm{c}}$ & $392.86 \pm 3.24^{\mathrm{a}}$ \\
Soaking & $3.67 \pm 0.03^{\mathrm{b}}$ & $15.15 \pm 2.26^{\mathrm{d}}$ & $5.16 \pm 0.36^{\mathrm{b}}$ & $7.08 \pm 0.36^{\mathrm{c}}$ & $62.24 \pm 2.43^{\mathrm{b}}$ & $373.29^{\mathrm{b}} \pm 3.34^{\mathrm{c}}$ \\
Germination & $3.60 \pm 0.03^{\mathrm{c}}$ & $20.21 \pm 0.63^{\mathrm{b}}$ & $5.32 \pm 0.42^{\mathrm{b}}$ & $7.39 \pm 0.36^{\mathrm{b}}$ & $54.85 \pm 0.77^{\mathrm{d}}$ & $366.75 \pm 2.95^{\mathrm{d}}$ \\
Boiling & $3.48 \pm 0.03^{\mathrm{d}}$ & $19.91 \pm 0.20^{\mathrm{b}}$ & $4.91 \pm 0.30^{\mathrm{c}}$ & $7.43 \pm 0.27^{\mathrm{b}}$ & $53.34 \pm 0.29^{\mathrm{d}}$ & $360.20 \pm 3.09^{\mathrm{e}}$ \\
CV & 0.69 & 3.55 & 3.55 & 2.15 & 1.97 & 1.02 \\
LSD & 0.04 & 1.09 & 0.28 & 0.27 & 1.94 & 6.40 \\
\hline
\end{tabular}

$\mathrm{CHO}=$ carbohydrate; $\mathrm{db}=$ dry weight basis; $\mathrm{CV}=$ coefficient of variation; $\mathrm{LSD}=$ least significant difference; values in a column with different letters show statistically significant differences of means -source: [41].

\subsection{Chickpea Has a High Market Value}

Chickpea grain can be marketed and or processed/value-added into several salable products in local, regional, and international markets to generate income, thus providing an opportunity for the engagement of different stake groups, referred to as value junctions. A key unique nature of chickpea is its versatile product chain of income generation power [22,36]. This emanates from its complex product development and transaction processes creating multiple opportunities so that different segments of 
societies can share them both in space and time. In Ethiopia, for instance, green pod marketing involves at least five value junctions [36], grain produce involves more than 10 value junctions [22], processed ready-to-use products in powder or whole-grain form have about 15 value junctions, and the seed chain has about five value junctions [46]. At each value junction, small or large scale, there are different (some of them new) actors involved. This effectively gives a chance for the gender group to accrue the benefits of the chickpea value chain at both on-farm or off-farm levels [47]. Table 2 summarizes chickpea value junctions (i.e., products), the value of the product against the grain, and the main actors at each junction that could serve as points of market interventions for further improvement.

Table 2. Chickpea value junctions and the main actors in the primary chickpea growing countries in SSA.

\begin{tabular}{|c|c|c|c|}
\hline Products & Value of the Raw Grain, \% & Main Value Actors & Reference \\
\hline Raw grain & 100 & \multirow{2}{*}{$\begin{array}{l}\text { household head } \\
\text { Household head, } \\
\text { women, boys }\end{array}$} & [22] \\
\hline Green pod & 300 & & [36] \\
\hline $\begin{array}{l}\text { Whole-grain-based } \\
\text { value-added products (soaked, } \\
\text { boiled, fried, puffed, sprouts, } \\
\text { salads, vegetable curry, kollo, } \\
\text { shiro, tamia, kicha, bukulti, } \\
\text { thithko, githeri, taamia (falafil) }\end{array}$ & Up to 300 & Girls, boys, shops & [46]; observation \\
\hline $\begin{array}{l}\text { Flour-based products (salty } \\
\text { snacks, sweets, condiments, } \\
\text { cake, biscuits, buns, } \\
\text { doughnuts, shimbraassa) }\end{array}$ & Up to 350 & Women, shop owners & Observation \\
\hline $\begin{array}{l}\text { De-husked-based value-added } \\
\text { product (split seed (dhal), } \\
\text { vegetable curry (dhal), soup) }\end{array}$ & Up to 200 & Women & Observation \\
\hline Seed & Up to 150 & Seed producers & {$[46,48,49]$} \\
\hline Fodder/feed & 10 & producers & Observation \\
\hline
\end{tabular}

In Ethiopia, much of the produce (75\%) is used for home consumption (e.g., food, seed, exchange) while the remaining $25 \%$ is supplied to the market [50]. The trend is reversed for improved technology intervention areas, where $82 \%$ of the product is supplied to the market [15]. This transformational process for improved technology intervention areas from subsistence farming to market oriented production system was facilitated by scaling-up of technologies through projects such as the Tropical Legumes projects $[35,51,52]$. The projects promoted improved varieties with market competitive traits and high yield that stimulated producers to a shift from subsistence to market-oriented farming.

Chickpea could be one important source of hard currency for countries from the international trade of grain and value-added products. The chickpea export market is dominated by few countries (Figure 2) with Australia accounting for an average of over 37.7\% of the global export for the last 2 decades (2000-2018) followed by Mexico (9.3\%), India (8.6\%), and Russia (6.6\%). The African chickpea product market share is low in terms of volume and value. African chickpea marketing is limited by product quality and quantity. There is limited processing for value addition to fetching a better price for products. For instance, African chickpea is exported as grain to Asian markets, often to the high-volume food processing companies in India and Pakistan, and then it is processed and marketed in high-value markets in Western countries. Ethiopia is the largest exporter in Africa, where it is the eighth top chickpea exporter in the world accounting for an average of approximately $3.5 \%$ of the global chickpea export market for the last 2 decades, followed by Tanzania with 1.7\% [4]. The export volume and export earnings from the crop have recently shown a moderate increase over the years in both Ethiopia and Tanzania. However, approximately $94 \%$ of the export from Ethiopia still goes to low-value markets. Kabuli types fetch higher market prices compared to Desi types with price differences ranging from $15 \%$ [15] to $36 \%$ [22]. 


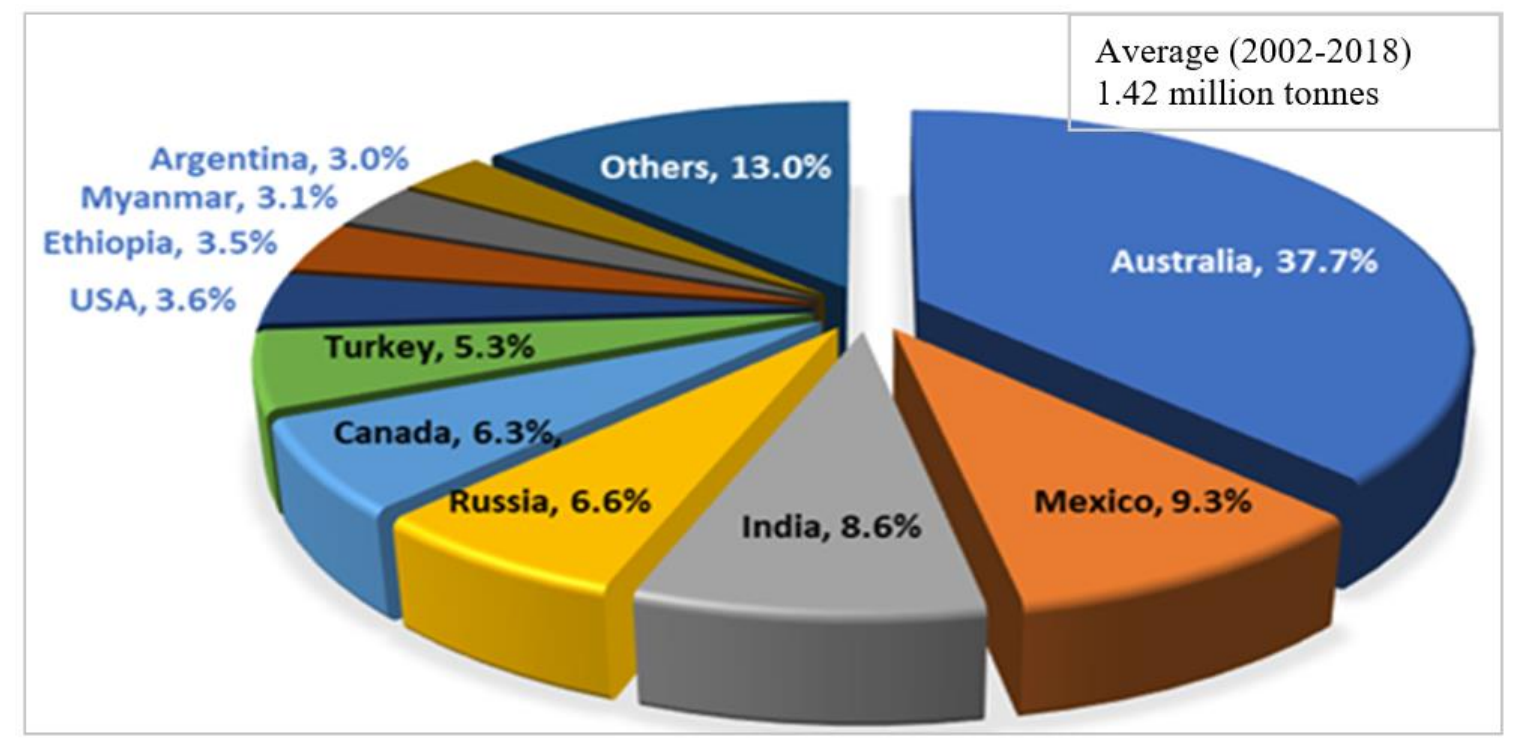

Figure 2. Major chickpea exporting countries (2000-2018) [4].

Improving the product quality standards of African chickpea is necessary to exploit the good global market potential in high-value markets. One important intervention area is improving access of certified seed to farmers through a strong and sustainable seed system that benefits all actors. Smallholder farmers source seeds for planting mainly from the informal system where traceability and quality are issues. Often, they plant a mixture of varieties which ultimately affects productivity and quality. Another intervention area is the mechanized harvesting and threshing process [53], which otherwise is mainly done manually using human labor and animals with significant quality and yield loss. Machine harvestable varieties are becoming available [54]. Machine harvestable varieties are labor-saving for lower cost of production and, hence, higher profit; enable quick harvest and therefore avoid damage to the mature crop from unfavorable weather (e.g., rain, wind, hailstorms) and other factors (e.g., theft, grazing); reduce drudgery (e.g., hardship, back pain, skin problems due to the acid on plants) on women; enable better interception of light in the plant canopy, and, hence, reduction in foliar diseases; enable effective spray of pesticides in plant canopy for better management of pod borers.

Cleaning machines that remove soils and other impurities are useful to improve quality. In reality, combine harvesters and cleaning machinery may not be affordable at the smallholder farmer level. Farmer organizations and private companies could be engaged to invest in machinery and provide services to farmers. In addition, private companies involved in chickpea processing and value addition could provide market incentives for encouraging farmers to ensure quality. Private processing companies could be linked with farmers for production and sustainable supply of quality chickpea with an agreed premium price. Farmers are not likely to invest time and resources for maintaining quality for a standard market where price premiums are lacking. Government support in providing incentives for private companies would encourage private companies to invest while market integration and support would help to assess and monitor the global market trend for channeling and expanding African chickpea export to high-value market within and outside the continent in a competitive environment.

\section{Retrospectives and Prospective of Chickpea in SSA}

Chickpea has so far been cultivated in some SSA countries mainly in the East and Southern Africa countries. Looking into prospective and retrospectives of the crop as well as the current climate calamities, chickpea is a high potential commodity option for SSA with a climate-smart nature, market competitiveness, nutrient-density, and with health food attributes while also ensuring the sustainability of agriculture. Non-traditional chickpea countries can be exploited based on their climatic, 
soils, cropping culture, and moisture regimes to expand the production area and volume. The rice system alone covers about 13 million ha in the region [4], which is one of the typical rice-chickpea integrated commercial cultures known to be paddy rice in Asia [24,55] and can be easily adapted to SSA. Gowda et al. [24] underlined that substantial rice-fallow areas available in several countries in SSA can be exploited, and earlier experiments demonstrated that chickpea is the most suitable pulse crop for rice-fallows, provided that suitable varieties and technologies for crop establishment are available. The most important traits required in chickpea varieties for rice-fallows include early (90-110 days) to extra-early ( $<90$ days) maturity and tolerance to reproductive stage heat stress [24]. The main rice-producing countries in SSA include Nigeria ( $3.35 \mathrm{M}$ ha), Guinea (1.86 M ha), DR Congo (1.3 M ha), Tanzania (1.2 M ha), Mali (0.97 M ha), Madagascar (0.93 M ha), Sierra Leone (0.8 M ha), and Cote d'Ivoire (0.77 M ha), while Cameroon, Ghana, Mozambique, Chad, Senegal, Burkina Faso, Benin, Guinea-Bissau, Uganda, Togo, Angola, Gambia, Malawi, Ethiopia, Burundi, Mauritania, and Rwanda devote significant area for rice [4]. Adding area for other principal cereals, such as wheat, maize, sorghum, millet [56], and tef production systems as well as vertisols, an estimated area of more than 100 million hectares in SSA could potentially be exploited for mainstreaming chickpea.

With a conservative estimate, chickpea can feasibly be produced on about $10 \%$ of the potentially exploitable cropping systems in the SSA region to effectively cover up to 10 million ha using rain-fed and/or irrigation systems. It could be mainstreamed in systems of double cropping, water retreat catchments, mono-cropping, relay cropping, rotational cropping or mixed cropping provided the right policy, promotion, and investment are made. For example, the production area in Ethiopia could be increased ten-fold from the 241,212 hectares in 2018 [4] by expanding the area in more than 50 districts in the central highlands, southern highlands, and the great rift valley [19,57]. Similarly, the area could be increased two-to-thousand-fold in other countries including Kenya (dry highlands: Bomet, Nakuru, Narok, Naivasha; medium altitude drylands: Embu, Mbeere, Garaba, parts of Nakuru; dry lowlands: Tana River, Kajiado, Baringo, Kerio Valley, Katumani, Machakos) [58], Mali (Niono, Attara, Diré, Tizongo, Tombouctou, Mopti, Lake zones, Niger zone) [59], Sudan (New Halfa in East Sudan, Jebel Marra and Kordofa in West Sudan, and the Gezira Scheme in central Sudan) [60], South Africa (Limpopo and Mpumalanga provinces and similar agro-ecologies) [61], Tanzania (Lake Zone: Shinyanga, Mwanza, Mara, Kagera regions, Western zone: Taboranaki, Goma regions; Northern zone: Manyara, Arusha regions) [62], and Zimbabwe (Natural Region III and IV as winter chickpea) [63]. The unique feature of chickpea compared with other legume crops is its ability to adapt and thrive in cold climates, which is often the case after the rice harvest and residual moisture chickpea cropping system. For example, from October to December, the temperature could drop to as low as $10-12{ }^{\circ} \mathrm{C}$ in West and Central Africa [64]. Legumes such as cowpea and groundnut do not perform well under such cold climates.

The SSA chickpea productivity is high compared to the global average, particularly in some countries such as Ethiopia, Sudan, and Zimbabwe (Figure 3). This is possibly attributed to the contribution of agroecological suitability, adoption of improved varieties, and better crop management. Higher yields of more than $3.5 \mathrm{t} /$ ha were realized in Ethiopia with the generation and adoption of improved technologies through support from the Tropical Legumes project [35], and some innovative farmers have reported yields up to $6 \mathrm{t} / \mathrm{ha}$. More than 48 chickpea varieties have been released in SSA since the 1970s including Ethiopia (29), Tanzania (4), Kenya (7), and Sudan (8). This high productivity potential could be exploited to expand production in the region. 


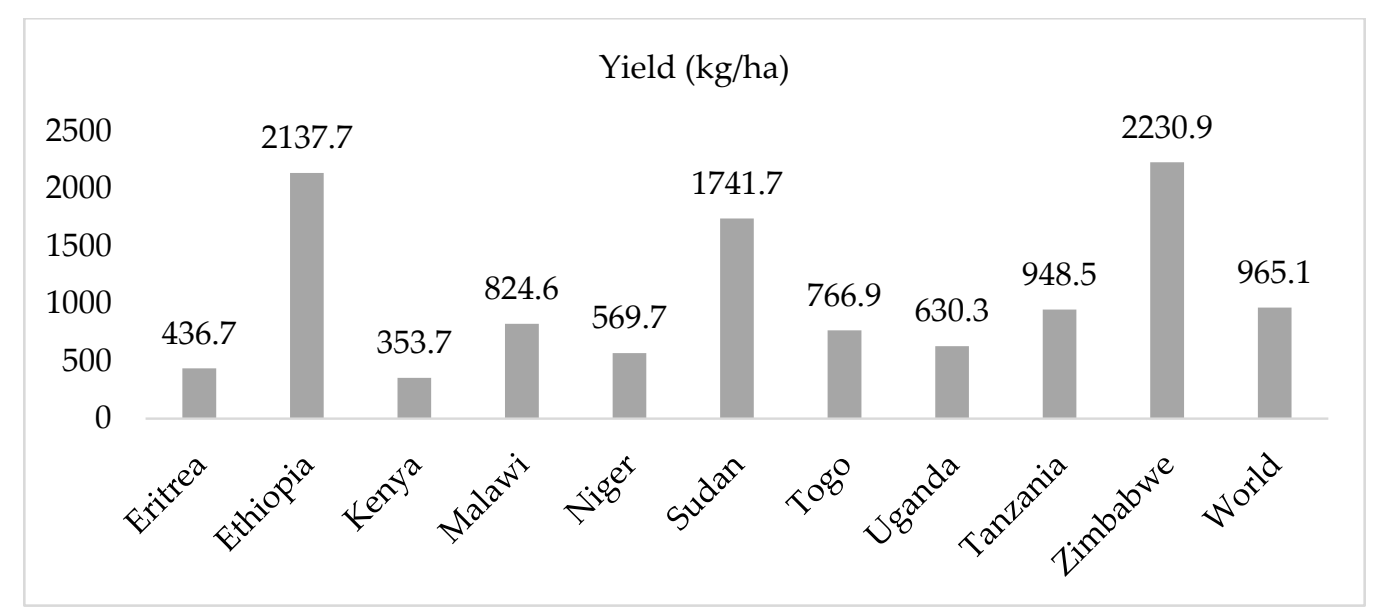

Figure 3. The productivity level of chickpea in SSA countries [14].

\section{Chickpea Research for Development Gaps in SSA}

The chickpea research for development (R4D) gaps in SSA, like other legumes, are multifaceted and varied including policy, promotion, market competitiveness, mechanization, productivity gaps, crop protection, and quality. These R4D gaps have been important barriers to the effective utilization of legumes as mainstream crops [65]. Some R4D challenges are summarized in Table 3 that can support strategic interventions. The level of policy and investment focus for the chickpea R4D remained a low priority in the region. By and large, the Tropical Legumes project (2007-2019) was a well-organized and consolidated project where chickpea R4D was supported in important chickpea-producing countries in SSA such as Tanzania, Ethiopia, and Kenya. The project invested in strengthening breeding programs, promotion of improved varieties, strengthening seed systems, and training researchers $[51,66]$. The transformation of chickpea from simple precursor to one of the principal crops $[19,67]$ contributing to the socio-economic development in Ethiopia is an important success story to learn and adapt to the other SSA geography of intervention. The Ethiopian chickpea program, one of the relatively well-organized programs in the region, has a strong government policy and financial support for conducting scientific research for development. In addition, it leverages financial and technical resources from time-bounded projects for investing in its capacity and fills specific R4D gaps. The synergy helped create a large increase in productivity gains in the crop $(>2 \mathrm{t} / \mathrm{ha})$ with steady progress. The long-established partnerships with ICRISAT (International Crops Research Institute for Semi-Arid Tropics) and ICARDA (International Center for Agricultural Research in the Dry Areas), who have a global mandate for chickpea improvement, has enabled the program to gain access to more than 10,000 germplasm resources [19] and skills exchange that enhanced the overall capacity, research performance, and effective technology delivery.

The experience in Ethiopia demonstrates that the government's role in mainstreaming chickpea among food security crops, creating an enabling environment, such as market access, providing incentives, and funding R4D, is critical for sustainable agricultural growth. Donor funded research and development projects could complement government investment to bring the required agricultural transformation in the region. The crop productivity and production gaps could be addressed through identifying suitably packed variety (high yielding, nutrient-dense, market preferred and resilient/adaptive variety) and developing appropriate agronomic management (irrigation, fertilization, cultivation) practices. The product quality gaps, such as grading, post-harvest management, seed processing, and agro-processing (value addition), require interventions of value chain actors, particularly the private sector. This way chickpea production, consumption, and marketing would be improved and countries would economically benefit. Chickpea, having the agro-ecological and climatic advantage, could have its jump start with these interventions to tap into its potential. 
Table 3. Major constraints and research gaps of chickpea in SSA.

\begin{tabular}{|c|c|c|}
\hline Factors & Constraints & Reference \\
\hline Productivity & $\begin{array}{c}\text { Low yield, yield gap, unavailability of } \\
\text { improved varieties }\end{array}$ & {$[35,65,68]$} \\
\hline Biotic stresses & $\begin{array}{l}\text { Ascochyta blight, fusarium wilt and root rot, pod } \\
\text { borer, viruses, bruchids }\end{array}$ & {$[19,58-60,62]$} \\
\hline Abiotic stresses & Terminal drought, heat, waterlogging, salinity & {$[10,24,58]$} \\
\hline Market traits/value addition & Nutrient-dense variety, seed size, market quality & [24] \\
\hline Agronomic & Cropping systems, cultural practices & {$[63,69,70]$} \\
\hline Mechanization & $\begin{array}{c}\text { Machine harvesting and threshing, cleaning, sorting } \\
\text { and grading machines }\end{array}$ & {$[53,54]$} \\
\hline Socio-economic factors & $\begin{array}{l}\text { Weak policy support, poor access to credit, poor } \\
\text { market access, poor access to inputs, weak seed and } \\
\text { agro-business system }\end{array}$ & {$[15,46,49,52,65,71]$} \\
\hline
\end{tabular}

\section{Chickpea Improvement Research in SSA}

\subsection{Understanding the Priorities of Farmers and Value Chain Actors}

Approximately $70 \%$ of the projected growth in crop production in sub-Saharan Africa between 1995/7 and 2030 is from yield increases [72], and much of the yield increase is often expected to come from genetic improvements through plant breeding. The goal of a breeding program is to develop improved varieties for the target population of environments (TPEs). Characterizing the environment and defining the TPE is an important step for a successful breeding program to minimize complex genotypes by environmental interactions [73,74]. This involves analyzing a variety of conditions, such as climate, soils, management practices, yield performance of crops, and trait preferences, to form a cluster of unique environment groups using different analytical approaches. Target population of environment refers to these clusters (sets) of environments in which improved crop varieties developed by a breeding program need to be adapted $[75,76]$. Chickpea breeding programs in SSA would have to strategize breeding centers to cluster sub-mega ecologies at scale based on climatic or soil commonalities, such as vertic soil, cropping systems, irrigation-based, warm/ thermal zones, and arid tropics, as well as socio-economic factors which dictate traits preference for technology development for greater gains from selection. Product development and commercialization for a target environment require, though it might be costly, rigorous testing of potential products at representative sites (selection population of environments (SPEs)) of the actual environment. Early generation nurseries and replicated trials with a large number of lines and varieties are conducted in the SPEs to predict their performance in the TPE $[75,77,78]$. The replicated trials are often referred to as multi-environment trials (METs) conducted to represent the TPE [79]. An effective SPE ensures a high genetic correlation between the TPE and the SPE. such that the rank of genotypes (lines/varieties) in it will be similar to their rank in the TPE. The SPE must also repeatably discriminate genotypes under evaluation to ensure high heritability, and it should permit a low-cost screening of relatively large numbers of genotypes for applying a high selection intensity.

Understanding the market (i.e., understanding the current priorities of farmers and value chain actors while also considering how priorities could evolve in the future) is another critical component for designing a demand-led breeding program [80-82] including a demand-led chickpea breeding program. This requires market research and foresight analysis to elucidate current and future market and consumer needs, and develop product profiles which describe the product uniquely as part of marketing as well as home consumption. The key features of a product profile include (1) the currently-grown variety (benchmark) to be replaced by the new product, (2) the features of the currently-dominant variety that must be retained in the new variety (i.e., must have traits) to ensure market acceptability, and (3) the improvements (value-added traits) that will be delivered in the new variety to guarantee that it will replace the currently grown variety for a target market. Investment 
case decisions are made to prioritize the traits for a given product profile based on the trait importance, technical feasibility (trait availability, ability to measure, genetic correlations), economic feasibility (cost of measurement, cost of genetic gain), level of the trait (distance from current to the desired level), and timing of the response (short to long term). Resources are rationalized to focus breeding pipelines on winning traits for efficiently developing products with larger economic impact. In chickpea, biotic and abiotic resistance, taste, and phenology traits are priority traits for breeding. In SSA, drought tolerance, early maturity, fusarium resistance, ascochyta blight resistance, salinity tolerance, and pest resistance are the focus for trait discoveries.

\subsection{Germplasm Enhancement and Breeding}

A global collection of approximately 100,000 chickpea germplasm accessions maintained in 120 national and international gene banks in 64 countries have been characterized for basic traits, with germplasm resource subsets developed for mining allelic diversity for breeding purposes [83]. Germplasms from the subsets have been utilized by breeding programs around the world for developing improved varieties. Chickpea breeding programs in SSA have been heavily reliant on ICARDA and ICRISAT. The programs have been conducting performance evaluations of breeding lines obtained from ICARDA and ICRISAT in the form of international chickpea screening nurseries and other forms of evaluation trials with no or limited real breeding (new breeding population development, early generation advancement, and screening) activities in the TPEs. This is manifested by the fact that the majority of the more than 48 chickpea varieties released in the region were sourced from ICARDA and/or ICRISAT chickpea improvement programs. In Ethiopia, for instance, 26 out of the 29 released varieties were identified from the performance evaluation of breeding lines developed by the two centers [19], while all varieties released in Sudan, Tanzania, and Kenya were developed by the two centers.

The evolving dynamics of genotype by environment interaction affects the success of varieties developed somewhere else to cope with constraints in another target area as well as the speed of trait discovery to mitigate the impact of a changing climate. Germplasm deployment from a non-target environment to a target environment is less efficient and effective as the varieties may not be readily fit to respond to the real-time prevailing constraints. For instance, aschochyta blight resistance germplasm resources developed at ICRISAT/ICARDA could not demonstrate the same level of resistance in Ethiopia despite evaluations of tens and thousands of lines in the last two decades [84]. It was only recently that two promising varieties (ICCV 10515 and ICCV 96836) were identified to have aschochyta blight resistance [85], and eventually ICCV-10515 was officially released and registered as 'Eshete' in 2020 for the first time [86]. Reddy et al. [87] has suggested that both crop and region-specific approaches are necessary to increase the production and area of pulse crops. This helps for strategic planning to address region-specific constraints with a scientific approach in a target region. Strengthening capacity for local and regional technology development and delivery is critical. The presence of strong breeding programs in SSA will have the "real-time" advantage to facilitate the development of target breeding populations and making advancement decisions at the SPE for the TPE. The strong breeding programs stand to benefit more from the backstopping of globally mandated CGIAR (Consultative Group for International Agricultural Research)centers and other emerging partnerships.

\subsection{Advanced Breeding Approaches for Existing and Emerging Challenges}

In the past, conventional breeding and crop improvement alone have brought chickpea improvements to the current level where a large number of high yielding improved chickpea varieties were developed worldwide [9]. Although conventional plant breeding contributed to increased yields [88], largely attributed to environmental adjustments, genotype, and their interaction [89], recent rates of yield increase have started to plateau [90]. Still, there is ample scope to improve productivity and climate resilience by developing improved varieties through enhancing the genetic diversity 
of breeding gene pools, speed breeding and precision phenotyping, and the integration of modern genomic resources with conventional breeding $[9,10,91]$.

The delivery of genetic gains in farmers' fields has been limited by a narrow genetic base in breeding gene pools, prolonged breeding cycles, delays in the adoption of modern technologies, and weak seed delivery systems in the past decades [91]. Enhancing genetic diversity using bi-parental or multi parental advanced generation intercross (MAGIC) recombination is important for addressing the persistent challenges of quantitative trait dissection. For chickpea, nested association mapping (NAM) and MAGIC populations are being developed to create diverse patterns of recombination by making inter-crosses among multiple $(4,8$ or 16$)$ parental lines of diverse origin to recombine mosaics of founder parents, leading to novel genotype and haplotype combinations. Through an analysis of 300 recombinant inbred lines (RILs) from ICARDA-MAGIC population, a high diversity for protein, ranging from $18 \%$ to $31 \%$, and high Fe and $\mathrm{Zn}$ contents $\left(>81 \mathrm{mg} \mathrm{Kg}^{-1}\right)$ weree reported [9]. The chickpea breeding cycle can be significantly shortened through speed breeding. Rapid generation advancement using greenhouse techniques with extended light treatment has demonstrated six generations per year [92], while a field-level experiment on the speeding cycle has demonstrated 4-6 generations per year [29]. This approach would significantly enhance genetic gain by reducing the breeding and variety development cycle and reducing the average age of improved varieties in farmers' fields. Chickpea breeding could also benefit from advances in high throughput phenotyping, drone-based crop monitoring and data capture technologies to improve selection accuracy and efficiency.

The integration of advanced biotechnology tools enables effective and efficient trait discovery to respond, along with innovative models of crop management, to emerging issues of yield, quality, phenology, and adaptation. With the recent advancement in next-generation sequencing (NGS) technology, extensive genetic, genomic, and transcriptomic resources have been developed to transform chickpea from an orphan crop to a genomic resource-rich crop $[67,93,94]$. The chickpea draft genome sequence [93] enables the use of sequencing-based approaches for chickpea improvement. In recent years, the genotyping by sequencing (GBS) approach has been used to detect genome-wide single nucleotide polymorphisms (SNPs) in chickpea to understand allelic diversity and population structure and develop high-density linkage maps, quantitative trait loci (QTL) analysis, genome-wide association studies (GWAS), and genomic selection (GS). For example, the GBS approach has widely been used for linkage mapping and QTL detection of ascochyta blight resistance [94], heat tolerance [95], seed iron and zinc contents [83], and seed quality [96], among others, using RIL populations in chickpea. The marker-assisted backcrossing (MABC) approach was successfully implemented at ICRISAT by introgressing a "QTL-hotspot" for drought tolerance from ICC 4958 to develop and release improved varieties in India and Ethiopia. Significant progress is also being made in the introgression of agronomic traits of interest by deploying genes from wild species of Cicer reticulatum and Cicer chinospermum to the cultivated Cicer arietinum [97]. It is anticipated that a sequence-based holistic breeding approach, including the integration of functional_omics, parental selection, forward breeding, and genome-wide selection, will bring a paradigm shift in the development of superior climate-resilient chickpea varieties with improved productivity. Chickpea breeding programs in SSA stand to exploit and benefit from these advancements. Utilization of these resources has become accessible relatively easily with the outsourcing of genotyping to service providers such as InterTek at a reasonable cost.

\section{Taking Chickpea to the "Last Mile"}

A study in Malawi and Tanzania demonstrated the value of climate-resilient seeds for smallholder adaptation in sub-Saharan Africa to climate change with the benefits of adopting resilient seeds ranging between USD $\$ 984$ million and 2.1 billion from 2020-2050 [98]. For chickpea to have expected impacts and contribute to an economic transformation in the face of climate change and variability, seeds of improved varieties with accompanying integrated crop management technologies must reach farmers and be utilized, and the variety turnover (replacement) rate in farmers' field needs to be significantly improved. This is possible through sustainable seed systems and strong extension (agricultural 
advisory) services. Cacho et al. [98] emphasized the benefits of establishing and maintaining a flexible national seed sector with participation by communities in the breeding, delivery, and adoption cycle. A sustainable seed system facilitates access to seeds of improved varieties by farmers. The chickpea seed business could be profitable and sustainable $[46,66]$. However, the chickpea seed system in SSA, as for many other legumes, remains weak and far from sustainable. The unreliable demand, autogamous nature, and slow variety replacement rate by smallholder farmers do not provide a strong incentive for private seed companies to invest in the legume seed business [52]. Hence, poor access for farmers to improved seeds with key quality attributes-physical and genetic purity; weed, pest, and diseases free; high germination; etc. [99]—at an affordable price remains the biggest challenge for the seed sector in agricultural development.

In SSA, the chickpea seed system has been facilitated so far by the initiation and operations of mainly community seed producer associations and cooperatives $[46,49,66]$, which are informal channels. Seed producer cooperatives have a comparative advantage of delivering seed to farming communities at an affordable price [100]. Sperling et al. [101] emphasized the need to focus on the informal seed channels and particularly on traders who move "potential seed" (informal or local seed) even to high-stress areas where commercial companies have closed shop (i.e., conflict zones) or where they have never set foot at all (e.g., remote areas with little infrastructure). The authors have proposed an initial framework to examine entry points of support to ensure informal markets can deliver the seed farmers want and need-via the contact point of traders. On the other hand, Akpo et al. [66] emphasized that, for sustainable and reliable seed production and delivery systems in SSA, a bold step is needed whereby the informal seed production entities are nurtured and upgraded into the formal certified seed production ventures that deliver social and economic benefits to the producers and the communities. In Ethiopia, seed producer associations, part of the informal seed system, are benefiting from business opportunities with income generation of more than USD $\$ 2000$ per hectare [19]. Some seed association groups have evolved into Pvt Plc, and three private companies have recently joined the chickpea seed business. These developments have contributed to a major shift in the chickpea seed system where previously $80-90 \%$ of seed was sourced from the informal system [102]; currently, the formal seed system is striving to capture the lion's share of the national seed market. Similar developments are happening in the Lake Zone of Tanzania, where chickpea is primarily grown as a cash crop with a relay cropping system after harvesting maize or rice. According to Ojiewo et al. [65], many non-governmental organizations (NGOs),community based organizations (CBOs), and seed companies have taken up active seed production, engaging individual farmers or groups of farmers on a contractual basis to produce certified seed and quality declard seed (QDS) to meet the new demand for seed required for this diversification. Based on analyses of four seed system case studies in Ethiopia, Myanmar, Tanzania, Nigeria, and Uganda, Ojiewo et al. [103] noted that market demand, successful partnerships and institutional linkages in the production and delivery of improved seed to smallholder farmers, and fostered conducive policies supported national seed systems are integral to grain legumes seed system viability and sustainability. It is safe to hypothesize that both the formal and informal seed systems remain important for grain legumes in the foreseeable future in SSA. The suggestion that, in the medium term, both formal and informal seed systems will have to be transformed to address agroecological and farming system challenges, partially shaped by global environmental changes [104], remains valid.

Awareness creation to increase demand for improved production technologies and linking farmers with the right market through extension services and policy support would enhance adoption thereby making a positive economic impact. The extension services in SSA, among the most important rural services, have a combination of challenges including a lack of relevant technology, failure of research and extension to understand and involve clientele in problem definition and solving, lack of incentives for extension agents, and weak linkages between extension, research, and farmers [71]. Strengthening the extension services requires establishing research and extension linkages to improve access to technologies by the extension system, effective extension service institutional structures, 
and incentivizing and capacity building of extension personnel through agricultural technical and vocational education and training (TVET) to upgrade their skills about new technologies and marketing. The clientele's involvement in problem definition and solving could be addressed through improved market segmentation and the product development process of the chickpea improvement. There are several extension service approaches [71], but pluralistic and participatory approaches including farmer training, agricultural technology demonstrations, field days, and farmer-to-farmer interactions are generally considered effective agricultural extension methods $[71,105,106]$. In recent years, information and communication technologies (ICTs) have been promoted as a promising way for agricultural extension provision in smallholder production systems in developing countries [107].

Agro-dealers could complement sustainable seed systems and functional extension systems. Agro-dealers, with agricultural input sale points distributed across the region including in a small village, could play a critical role in taking improved chickpea varieties to "the last mile", particularly to places where seed companies may not reach. They have been proved useful to gain access to improved seeds in required quantities including small seed packs [51,101,103] where farmers could buy small quantities at an affordable price to test before going large scale. As pointed out by the AGRA, farming in low-income countries will need to evolve rapidly to remain competitive and gain access to growing urban markets [6]. Farmers will need to produce farm goods which will be increasingly standardized in variety, size, taste, quality, and safety. They will need to increase flexibility in their decision-making process, which implies having better access to input and output streams [6]. Production must be driven by value chains organized to meet increasingly diversified food demand [5]. Policy support and market integration to link farmers with the right market would incentivize both farmers to increase productivity by adopting improved technologies and exporters.

\section{Summary and Conclusions}

Chickpea has a huge potential to contribute to the economic development of SSA and benefit the value chain actors. However, production, home consumption, and marketing volume of the crop are low compared with global data. The mainstreaming of chickpea in the different cereal dominated cropping systems in the region, including the rice-fallow system would allow exploiting the economic potential of chickpea. The integration of chickpea in different cropping systems will have multiple benefits through, among others, the yield obtained from chickpea (i.e., cumulative intensification), a yield increase of the subsequent crop due to the nitrogen-fixing capacity (saves $\sim 1 / 3$ rd $N$ fertilizer), and ensures environmental sustainability. Among others, three complementary areas of intervention will be important to tap the economic potential of the crop. (1) The policy environment needs to consider mainstreaming chickpea as one of the strategic crops for the economic development agenda by providing incentives for private sector investment and supporting product marketing. Evidence-based advocacy efforts are required on the values and potential economic contributions to regional (i.e., Intergovernmental Authority on Development (IGAD), Economic Community of West African States (ECOWAS), and Alliance for a Green Revolution in Africa (AGRA)) and respective countries' decision-makers for putting in place the regulatory frameworks and structures that foster a strong business environment for chickpea. (2) The strengthening of the research and development environment is key for realizing the benefit of chickpea. Strategic investments in technology development and promotion would be critical to develop products that have market demand (including improved varieties) and disseminate to farmers and other stakeholders. These include investments in infrastructure, personnel, facilities, and strengthening the skills of scientists and extension specialists to build local and regional capacities. Local and regional capacities enable the development and transfer of market demanded products with a high adoption rates and economic impacts. Research and development efforts should also tap into recent advances in science. Strengthening seed systems and extension services would help to improve access to improved seeds and other inputs to smallholder farmers. (3) Utilization, value addition, and market promotion would be critical. Chickpea has culinary values widely used globally which could be significantly expanded to 
SSA. Chickpea import to SSA has been increasing over the years with countries such as Sudan, Eritrea, Gambia, South Africa, Senegal, Angola, Niger, and DR Congo importing large quantities every year [4] suggesting an increased role of chickpea in recipes in SSA. The import market could be captured by improving local production and marketing, hence, improving the income of actors and saving hard currency for the respective country. Nutrition research (e.g., biofortification, recipes) and advisory services could help in popularizing different recipes and developing value-added products that could be used for home consumption and local and global markets. Increased home consumption of chickpea helps to reduce malnutrition. Improving product quality and adding value could enhance economic benefits by exploiting high-value export markets. This, in turn, will have a cascading impact on communities including women and youth and provide multiple junctions of livelihood opportunities.

Author Contributions: Writing-original draft preparation, A.F.; writing-review and editing, H.D. and S.A.; visualization, H.D. All authors have read and agreed to the published version of the manuscript.

Funding: The article processing charge (APC) was funded by Bill and Melinda Gates Foundation (BMGF). They also supported the chickpea research and development in SSA from 2007 to 2019 under the Tropical Legumes Projects in selected countries where the authors participated in the implementation of project activities.

Conflicts of Interest: The authors declare no conflict of interest. The funders had no role in the design of the study; in the collection, analyses, or interpretation of data; in the writing of the manuscript, or in the decision to publish the results.

\section{References}

1. Alliance for A Green Revolution in Africa (AGRA). Transforming Africa's Agriculture for Sustainable Inclusive Growth, Improved Livelihoods and Shared Prosperity. In Proceedings of the Background Note for High-Level Side Event on African Economic Transformation Held in the Margins of the Third International Conference on Financing for Development, Addis Ababa, Ethiopia, 13-16 July 2015.

2. PARI. From Potentials to Reality: Transforming Africa's Food Production. Program of Accompanying Research for Agricultural Innovation (PARI). 2020. Available online: https://www.zef.de/fileadmin/downloads/ZEF_ Akademiya2063.pdf (accessed on 12 October 2020).

3. OECD/FAO. Agriculture in Sub-Saharan Africa: Prospects and Challenges for the Next Decade. In OECD-FAO Agricultural Outlook 2016-2025; OECD Publishing: Paris, France, 2016. [CrossRef]

4. FAOSTAT 2020. Available online: https://www.fao.org/faostat/en/\#data (accessed on 23 August 2020).

5. NEPAD. African Agriculture, Transformation and Outlook; New Partnership for African Development (NEPAD): Johannesburg, South Africa, 2013; 72p.

6. AGRA. Africa Agriculture Status Report 2016: Progress towards Agricultural Transformation in Africa; Alliance for a Green Revolution in Africa (AGRA): Nairobi, Kenya, 2016.

7. Turner, N.C.; Wright, G.C.; Siddique, K.H.M. Adaptation of grain legumes (pulses) to water-limited environments. Adv. Agron. 2001, 71, 193-231. [CrossRef]

8. African Development Bank Group. Africa in 50 Years' Time: The Road Towards Inclusive Growth; Working Document; African Development Bank: Tunis, Tunisia, 2011; 72p.

9. Roorkiwal, M.; Bharadwaj, C.; Barmukh, R.; Dixit, G.P.; Thudi, M.; Gaur, P.M.; Chaturvedi, S.K.; Fikre, A.; Hamwieh, A.; Kumar, S.; et al. Integrating genomics for chickpea improvement: Achievements and opportunities. Theor. Appl. Gen. 2020, 133, 1703-1720. [CrossRef] [PubMed]

10. Gaur, P.M.; Samineni, S.; Thudi, M.; Tripathi, S.; Sajja, S.B.; Jayalakshmi, V.; Mannur, D.M.; Vijayakumar, A.G.; Gangarao, N.V.P.R.; Ojiewo, C.O.; et al. Integrated breeding approaches for improving drought and heat adaptation in chickpea (Cicer arietinum L.). Plant Breed. 2018, 1-12. [CrossRef]

11. Berger, J.D.; Turner, N.C. The ecology of Chickpea. In Chickpea Breeding and Management; Yadav, R., Chen, S., Eds.; CAB International, Cromwell Press: Trowbridge, UK, 2007; pp. 47-71.

12. ICB. International Crop Biodiversity; ICB: Addis Ababa, Ethiopia, 2012.

13. Anbessa, Y.; Bejiga, G. Evaluation of Ethiopian chickpea landraces for tolerance to drought. Genet. Resour. Crop Evol. 2002, 49, 557-564. [CrossRef] 
14. FAOSTAT 2018. Available online: https://www.fao.org/faostat/en/\#data (accessed on 20 March 2020).

15. Ferede, S.; Fikre, A.; Ahmed, S. Assessing the Competitiveness of Smallholders Chickpea Production in the Central Highlands of Ethiopia. Ethiop. J. Crop Sci. 2018, 6, 51-65.

16. Ouédraogo, M.; Zougmoré, R.; Moussa, A.S.; Partey, S.T.; Thornton, P.K.; Kristjanson, P.; Ndour, N.Y.B.; Somé, L.; Naab, J.; Boureima, M.; et al. Markets and climate are driving rapid change in farming practices in Savannah West Africa. Reg. Environ. Chang. 2017, 17, 437-449. [CrossRef]

17. Serdeczny, O.; Adams, S.; Baarsch, F.; Coumou, D.; Robinson, A.; Hare, W.; Schaeffer, M.; Perrette, M.; Reinhardt, J. Climate change impacts in Sub-Saharan Africa: From physical changes to their social repercussions. Reg. Environ. Chang. 2017, 17, 1585-1600. [CrossRef]

18. Verkaart, S.; Mausch, K.; Claessens, L.; Giller, K.E. A recipe for success? Learning from the rapid adoption of improved chickpea varieties in Ethiopia. Int. J. Agric. Sustain. 2019, 17, 34-48. [CrossRef]

19. Fikre, A. Progresses of chickpea research and development in Ethiopia. In Proceedings of the Harnessing Chickpea Value Chain for Nutrition Security and Commercialization of Smallholder Agriculture in Africa, Debre Zeit, Ethiopia, 30 January-2 February 2016; Korbu, L., Damite, T., Fikre, A., Eds.; EIAR: Addis Abäba, Ethiopia, 2016. Available online: http://oar.icrisat.org/id/eprint/9977 (accessed on 15 March 2020).

20. Godfray, H.C.J.; Beddington, J.R.; Crute, I.R.; Haddad, L.; Lawrence, D.; Muir, J.F.; Pretty, J.; Robinson, S.; Thomas, S.M.; Toulmin, C. Food Security: The Challenge of Feeding 9 Billion People. Science 2010, 327, 812-818. [CrossRef]

21. Jemberu, T.; Fikre, A.; Abeje, Y.; Tebabal, B.; Worku, Y.; Jorgi, T. Agronomic and Economic Evaluation of Wheat-Chickpea Double Cropping on the Vertisol of Takusa, North Western Ethiopia. Ethiop. J. Crop Sci. 2018, 6, 67-78.

22. Shiferaw, B.; Jones, R.; Silim, S.; Tekelewold, H.; Gwata, E. Analysis of production costs, market opportunities and competitiveness of Desi and Kabuli chickpeas in Ethiopia. In IPMS (Improving Productivity and Market Success) of Ethiopian Farmers Project Working Paper 3; ILRI (International Livestock Research Institute): Nairobi, Kenya, 2007; 48p.

23. Korbu, L.; Tafes, B.; Kassa, G.; Mola, T.; Fikre, A. Unlocking the genetic potential of chickpea through improved crop management practices in Ethiopia. A review. Agron. Sustain. Dev. 2020, 40, 13. [CrossRef]

24. Gowda, C.L.L.; Gaur, P.M.; Samineni, S. Chickpea Research and Development: Current Status and Future Perspectives in the Semi-arid Tropics. In Proceedings of the Harnessing Chickpea Value Chain for Nutrition Security and Commercialization of Smallholder Agriculture in Africa, Debre Zeit, Ethiopia, 30 January-2 February 2016; Korbu, L., Damite, T., Fikre, A., Eds.; EIAR: Addis Abäba, Ethiopia, 2016. Available online: http://oar.icrisat.org/id/eprint/9977 (accessed on 15 March 2020).

25. Geleto, T.; Nefo, K.; Tadesse, T. Crop rotation effects on grain yield and yield components of bread wheat in the Bale highlands of southeastern Ethiopia. In Proceedings of the Eleventh Regional Wheat Workshop for Eastern, Central and Southern Africa, Addis Ababa, Ethiopia, 18-22 September 2000; CIMMYT: Addis Ababa, Ethiopia, 2000; pp. 316-324.

26. Gizaw, B.; Tsegay, Z.; Tefera, G.; Aynalem, E.; Abatneh, E.; Amsalu, G. Traditional Knowledge on Teff (Eragrostis tef) Farming Practice and Role of Crop Rotation to Enrich Plant Growth Promoting Microbes for Soil Fertility in East Showa: Ethiopia. Agric. Res. Technol. 2019, 16. [CrossRef]

27. Okori, P.; International Crop Rsearch Institute for Semi-Arid Tropics, Lilongwe, Malawi. Personal communication, 2018.

28. Joachim, J.; LZARDI-Ukiriguru, Tanzania, Tanzania. Personal communication, 2018.

29. Fikre, A.; Degefu, T. A Guide to Accelerated Breeding Cycle in Chickpea to Enhance Rate of Gain; Technical Manual No. 1/2019; ICRISAT: Addis Ababa, Ethiopia, 2019.

30. Girma, N.; Fikre, A.; Ojiewo, C.O. The Genotypic and Phenotypic Basis of Chickpea (Cicer arietinum L.) Cultivars for Irrigation-Based Production in Ethiopia. J. Agric. Sci. 2017, 9, 229-236. [CrossRef]

31. Yemenu, F.; Eshetu, M.; Korbu, L. Assessment of Water Requirements of Chickpea grown in the Central Vertisol Areas of Ethiopia. In Proceedings of the Harnessing Chickpea Value Chain for Nutrition Security and Commercialization of Smallholder Agriculture in Africa, Debre Zeit, Ethiopia, 30 January-2 February 2016; Korbu, L., Damite, T., Fikre, A., Eds.; EIAR: Addis Abäba, Ethiopia, 2016. Available online: http://oar.icrisat. org/id/eprint/9977 (accessed on 15 March 2020). 
32. Tabe-Ojonga, M.P., Jr.; Kai, M. Impacts of Improved Chickpea Adoption on Smallholder Production and Commercialization in Ethiopia. In Proceedings of the Tropentag 2017, Bonn, Germany, 20-22 September 2017.

33. Bontpart, T.; Concha, C.; Giuffrida, V.; Robertson, I.; Admkie, K.; Degefu, T.; Girma, N.; Tesfaye, K.; Haileselassie, T.; Fikre, A.; et al. Affordable and Robust phenotyping framework to analyze root system architecture of soil-grown plants. Plant J. 2019, 103, 2330-2343. [CrossRef]

34. Kassie, M.; Shiferaw, B.; Asfaw, S.; Abate, T.; Muricho, G.; Ferede, S.; Eshete, M.; Assefa, K. Current Situation and Future Outlooks of the Chickpea Sub-sector in Ethiopia. In Survey Report; ICRISAT: Nairobi, Kenya, 2009.

35. Fikre, A. An overview of chickpea improvement research program in Ethiopia. J. Int. Leg. Soc. 2014, 3, 47-49.

36. Wondimu, Y.; Fikre, A. The Economics of Targeting and Sustaining a Niche Market: A Case Study of Green Pod Chickpea Marketing in Ethiopia. J. Econ. Sustain. Dev. 2019, 10, 40-52. [CrossRef]

37. Purushothaman, R.; Krishnamurthy, L.; Upadhyaya, H.D.; Vadez, V.; Varshney, R.K. Root traits confer grain yield advantages under terminal drought in chickpea (Cicer arietinum L.). Field Crop. Res. 2017, 201, $146-161$. [CrossRef]

38. Mola, T.; Alemayehu, S.; Fikre, A.; Ojiewo, C.O.; Alemu, K.; Degefu, T. Heat Tolerance Responses of Chickpea (Cicer arietinum L.) Genotypes in the Thermal Zone of Ethiopia, a Case of Werer Station. Ethiop. J. Crop Sci. 2018, 6, 95-118.

39. Alemayehu, S. Screening of Chickpea (Cicer Arietinum L.) Genotypes for Heat Stress Tolerance Under Lowland Irrigated Condition of Middle Awash Rift Valley, Ethiopia. Master's Thesis, Ambo University, Ambo, Ethiopia, 2017.

40. Than, A.M.; Maw, J.B.; Aung, T.; Gaur, P.M.; Gowda, C.L.L. Development and adoption of improved chickpea varieties in Myanmar. J. SAT Agric. Res. 2007, 5, 1-3. Available online: http://oar.icrisat.org/2573/ (accessed on 15 June 2020).

41. Olika, E.; Abera, S.; Fikre, A. Effect of Processing Methods on Proximate Composition and Functional Properties of Improved Chickpea (Cicer arietinum L.) Varieties Grown in Ethiopia. Food Sci. Qual. Manag. 2018, 72, 36-42. Available online: https://iiste.org/Journals/index.php/FSQM/article/view/40992/42150 (accessed on 15 March 2020).

42. Olika, E.; Abera, S.; Fikre, A. Physicochemical Properties and Effect of Processing Methods on Mineral Composition and Antinutritional Factors of Improved Chickpea (Cicer arietinum L.) Varieties Grown in Ethiopia. Int. J. Food Sci. 2019, 9614570, 1-7. [CrossRef]

43. Jukanti, A.K.; Gaur, P.M.; Gowda, C.L.L.; Chibbar, R.N. Nutritional quality and health benefits of chickpea (Cicer arietinum L.): A review. Br. J. Nutr. 2012, 108, S11-S26. [CrossRef]

44. Becerra-Tomas, N.; Díaz-Lopez, A.; Rosique-Esteban, N.; Ros, E.; Buil-Cosiales, P.; Corella, D.; Estruch, R.; Fito, M.; Serra-Majem, L.; Fernando, A.; et al. Legume consumption is inversely associated with type 2 diabetes incidence in adults: A prospective assessment from the PREDIMED study. Clin. Nutr. 2018, 37, 906-913. [CrossRef]

45. Zafar, T.A.; Kabir, Y. Chickpeas suppress postprandial blood glucose concentration, and appetite and reduce energy intake at the next meal. J. Food Sci. Technol. 2017, 54, 987-994. [CrossRef] [PubMed]

46. Chichaybelu, M.; Geleta, T.; Girma, N.; Fikre, A.; Eshete, M.; Ojeiwo, C.O. Innovative Partnership in Chickpea Seed Production and Technology Dissemination: A Decade of Lessons in Ethiopia. Ethiop. J. Crop Sci. 2018, $6,1-18$.

47. Zegeye, F.; Mussema, R.; Eshete, M.; Aliy, S.; Fikre, A. Gender in chickpea research and development of Ethiopia: Achievements, challenges and future direction. In Proceedings of the Harnessing Chickpea Value Chain for Nutrition Security and Commercialization of Smallholder Agriculture in Africa, Debre Zeit, Ethiopia, 30 January-2 February 2016; Korbu, L., Damite, T., Fikre, A., Eds.; EIAR: Addis Abäba, Ethiopia, 2016. Available online: http://oar.icrisat.org/id/eprint/9977 (accessed on 15 March 2020).

48. Bekele, N.; Tesso, B.; Fikre, A. Assessment of seed quality parameters in different seed sources of chickpea (Cicer arietinum L.). Afr. J. Agric. Res. 2019, 14, 1649-1658. [CrossRef]

49. Eshete, M.; Aliye, S.; Fikre, A.; Ojiewo, C.O. Community Seed Production of Chickpea (Cicer arietinum L.) and Lentil (Lens culinaris Medic) in Ethiopia. In Community Seed Production. Workshop Proceedings, 9-11 December 2013; Ojiewo, K., Bishaw, R., Eds.; FAO: Rome, Italy; ICRISAT: Addis Ababa, Ethiopia, 2015; pp. 80-87. 
50. CSA (Central Statistical Authority). Crop Production Forecast Sample Survey; Statistical Bulletin; CSA: Addis Ababa, Ethiopia, 2015.

51. Monyo, E.; Varshney, R.K. Seven Seasons of Learning and Engaging Smallholder Farmers in the Drought-Prone Areas of Sub-Saharan Africa and South Asia through Tropical Legumes, 2007-2014; ICRISAT: Patancheru, India, 2016; ISBN 978-92-9066-568-7.

52. Rubyogo, J.-C.; Akpo, E.; Omoigui, L.; Gaur, P.; Chaturvedi, S.K.; Fikre, A.; Desmae, H.; Hakeem, A.; Monyo, E.; Nkalubo, S.; et al. Market-led options to scale up legume seeds in developing countries: Experiences from the Tropical Legumes Project. Plant Breed. 2019, 1-13. [CrossRef]

53. Parkinson, N. Africa's Top Chickpea Producer Brings First Industrial Processing Machine. GoodFood World. Available online: http://www.goodfoodworld.com/2015/09/africas-top-chickpea-producer-bringsfirst-industrial-processing-machine-online-in-2015/ (accessed on 20 June 2020).

54. Madhuri, R.D.; Jayalakshm, V. Identification of high yielding mechanical harvestable chickpea (Cicer arietinum L.) genotypes under rainfed and irrigated conditions. Int. J. Chem. Stud. 2020, 8, 368-375. [CrossRef]

55. Pande, S.; Sharma, M.; Ghosh, R.; Rao, S.K.; Sharma, R.N.; Jha, A.K. Opportunities for Chickpea Production in Rainfed Rice Fallows of India-Baseline Survey Report; Grain Legumes Program Report No. 1; International Crops Research Institute for the Semi-Arid Tropics: Patancheru, Andhra Pradesh, India, 2012; 56p.

56. Macauley, H.; Tabo, R. Cereal Crops: Rice, Maize, Millet, Sorghum, Wheat. In Feeding Africa-Action Plan for African Agricultural Transformation; African Development Bank Group (AfDB): Tunis, Tunisia, 2015.

57. Demeke, N. GIS-Based Land Suitability Mapping for Legume Crops Technology Targeting and Scaling-Up. Ethiop. J. Crop Sci. 2018, 6, 180-198.

58. Kimurto, P.K.; Towett, B.K.; Mulwa, R.M.S.; Macharia, D.; Gatongi, I.M.; Njogu, N.; Oyier, M.; Lilian, J.; Kosgei, A.; Songok, S.; et al. An overview of chickpea research and development programs in Kenya: Current status, challenges and opportunities. In Proceedings of the Harnessing Chickpea Value Chain for Nutrition Security and Commercialization of Smallholder Agriculture in Africa, Debre Zeit, Ethiopia, 30 January-2 February 2016; Korbu, L., Damite, T., Fikre, A., Eds.; EIAR: Addis Abäba, Ethiopia, 2016. Available online: http://oar.icrisat.org/id/eprint/9977 (accessed on 15 March 2020).

59. Gaur, P.M.; Samaké, O. Feasibility of Growing Chickpea for Crop Diversification in Northern Mali; Survey Report; ICRISAT: Hyderabad, India, 2006.

60. Khalifa, G.E.; Hamed, A.A.; Adam, A. Review of Chickpea Production, Opportunities, and Challenges in Sudan. In Proceedings of the Harnessing Chickpea Value Chain for Nutrition Security and Commercialization of Smallholder Agriculture in Africa, Debre Zeit, Ethiopia, 30 January-2 February 2016; Korbu, L., Damite, T., Fikre, A., Eds.; EIAR: Addis Abäba, Ethiopia, 2016. Available online: http://oar.icrisat.org/id/eprint/9977 (accessed on 15 March 2020).

61. University of Venda. A Pilot Project Indicates Success in Chickpea Production by Local Farmers in South Africa. 9 October 2018. Available online: https://www.univen.ac.za/news/a-pilot-project-indicates-successin-chickpea-production-by-local-farmers-in-south-africa/ (accessed on 30 July 2020).

62. Kileo, R.O.; Joseph, J.; GangaRao, N.V.P.R. Prospects of chickpea improvement research and development in Tanzania: Challenges and opportunities. In Proceedings of the Harnessing Chickpea Value Chain for Nutrition Security and Commercialization of Smallholder Agriculture in Africa, Debre Zeit, Ethiopia, 30 January-2 February 2016; Korbu, L., Damite, T., Fikre, A., Eds.; EIAR: Addis Abäba, Ethiopia, 2016. Available online: http://oar.icrisat.org/id/eprint/9977 (accessed on 15 March 2020).

63. Maya, M.; Maphosa, M. Current status of chickpea production: Opportunities for promoting, adoption and adapting the crop in Zimbabwe: A review. J. Dryland Agric. 2020, 6, 1-9. [CrossRef]

64. Weather and Climate Information. Available online: https://weather-and-climate.com/ (accessed on 20 September 2020).

65. Ojiewo, C.O.; Rubyogo, J.C.; Wesonga, J.M.; Bishaw, Z.; Gelalcha, S.W.; Abang, M.M. Mainstreaming Efficient Legume Seed Systems in Eastern Africa: Challenges, Opportunities and Contributions towards Improved Livelihoods; License: CC BY-NC-SA 3.0 IGO; Food and Agriculture Organization of the United Nations: Rome, Italy, 2018; 72p. 
66. Akpo, E.; Feleke, G.; Fikre, A.; Chichaybelu, M.; Ojiewo, C.O.; Varshney, R.K. Analyzing Pathways of Nurturing Informal Seed Production into Formal Private Ventures for Sustainable Seed Delivery and Crop Productivity: Experiences from Ethiopia. Sustainability 2020, 12, 6828. [CrossRef]

67. Varshney, R.K.; Hiremath, P.J.; Lekha, P.; Kashiwagi, J.; Balaji, J.; Deokar, A.A.; Vadez, V.; Xiao, Y.; Srinivasan, R.; Gaur, P.M.; et al. A comprehensive resource of drought- and salinity- responsive ESTs for gene discovery and marker development in chickpea (Cicer arietinum L.). Genomics 2009, 10, 523. [CrossRef]

68. Saxena, N.P.; Johansen, C. Realizing yield potential in chickpea and physiological considerations for further genetic improvement. In Proceedings of the International Congress of Plant Physiology, New Delhi, India, 15-20 February 1988; Sinha, S., Bhargava, A., Eds.; Society for Plant Physiology and Biochernistry: New Delhi, India, 1988; pp. 279-288. Available online: http://oar.icrisat.org/4479/ (accessed on 15 March 2020).

69. Kirnak, H.; Varol, I.S.; Irik, H.A.; Ozaktan, H. Effects of irrigation applied at different growth stages on chickpea yield. Agron. Res. 2017, 15, 1928-1933. [CrossRef]

70. Rocha, I.; Duarte, I.; Ma, Y.; Souza-Alonso, P.; Látr, A.; Vosátka, M.; Freitas, H.; Oliveira, R.S. Seed Coating with Arbuscular Mycorrhizal Fungi for Improved Field Production of Chickpea. Agronomy 2019, 9, 471. [CrossRef]

71. Davis, K.E. Extension in Sub-Saharan Africa: Overview and Assessment of Past and Current Models, and Future Prospects. J. Int. Agric. Ext. Educ. 2008, 15, 1-14. [CrossRef]

72. FAO. World Agriculture: Towards 2015/30; Summary Report; FAO: Rome, Italy, 2002.

73. Alabi, T.R.; Adebola, P.O.; Asfaw, A.; De Koeyer, D.; Lopez-Montes, A.; Asiedu, R. Spatial Multivariate Cluster Analysis for Defining Target Population of Environments in West Africa for Yam Breeding. IJAGR 2019, 10, 1-30. [CrossRef]

74. Chenu, K.; Cooper, M.; Hammer, G.L.; Mathews, K.L.; Dreccer, M.F.; Chapman, S.C. Environment characterization as an aid to wheat improvement: Interpreting genotype-environment interactions by modelling water-deficit patterns in North-Eastern Australia. J. Exp. Bot. 2011, 62, 1743-1755. [CrossRef]

75. Cooper, M.; Stucker, R.E.; DeLacy, I.H.; Harch, B.D. Wheat Breeding Nurseries, Target Environments, and Indirect Selection for Grain Yield. Crop. Sci. 1997, 37, 1168-1176. [CrossRef]

76. Nyquist, W.E. Estimation of heritability and prediction of selection response in plant populations. Crit. Rev. Plant Sci. 1991, 10, 235-322. [CrossRef]

77. Cooper, M.; Hammer, G.L. Synthesis of strategies for crop improvement. In Plant Adaptation and Crop Improvement; Cooper, H., Ed.; CABI: Wallingford, UK, 1996; pp. 591-623.

78. Ceccarelli, S.; Grando, S. Selection environment and environmental sensitivity in barley. Euphytica 1991, 57, 157-167. [CrossRef]

79. Podlich, D.W.; Cooper, M. QU-GENE: A simulation platform for quantitative analysis of genetic models. Bioinformatics 1998, 14, 632-653. [CrossRef]

80. Kimani, P.M.; Anthony, V.M. Advances in market-oriented approaches for legume breeding in eastern Africa. Afr. J. Rural Dev. 2019, 4, 305-322. Available online: http://www.afjrd.org/jos/index.php/afjrd/article/view/ 2048 (accessed on 20 July 2020).

81. Persley, G.J.; Anthony, V.M. The Business of Plant Breeding: Market-Led Approaches to New Variety Design in Africa; CABI: Wallingford, UK; Boston, MA, USA, 2017; 210p.

82. Yao, N.K.; Kimani, P.; Hussein, S.; Tongoona, P. Demand-Led Variety Design: Make Plant Breeding in Africa a Business Model Responsive to Market Demand. In Proceedings of the International Tropical Agriculture Conference 2017 (TropAg2017), Brisbane, Australia, 20-22 November 2017. Poster. [CrossRef]

83. Upadhyaya, H.D.; Dwivedi, S.L.; Sharma, S. Managing and discovering agronomically beneficial traits in chickpea germplasm collections. In The Chickpea Genome; Varshney, R., Thudi, M., Muehlbauer, F., Eds.; Springer International Publishing: Cham, Switzerland, 2017; pp. 43-52. [CrossRef]

84. Debre Zeit Research Center (DZARC) Annual Report; DZARC: Debre Zeit, Ethiopia, 2018.

85. Fikre, A. Improving chickpea production to create wider welfare impact by leveraging technology and seed system development. Bulletin of Tropical Legumes. 2018. Available online: http://tropicallegumes.icrisat.org/ wp-content/uploads/2018/05/TL-III-Bulletin-11_Final.pdf (accessed on 2 November 2020). 
86. Girma, N.; Fikre, A. The Myth of Ascochyta Blight Devastation in Desi Chickpea finally Curbed: A Ground-Breaking News for Chickpea Farmers; Ethiopian Institute of Agricultural Research (EIAR): Addis Ababa, Ethiopia; Available online: https://www.facebook.com/EIARPR/posts/1705437109610338 (accessed on 20 September 2020).

87. Reddy, A.; Bantilan, M.C.S.; Mohan, G. Pulses Production Scenario: Policy and Technological Options. Policy Briefs. 2013. Available online: http://oar.icrisat.org/6812/1/26_Policy_BriefIndia\%20_2013.pdf (accessed on 15 March 2020).

88. Innes, N.L. The contribution from conventional plant-breeding. Proc. R. Soc. Edinburgh. Sect. B Boil. Sci. 1992, 99, 1-10. [CrossRef]

89. Simmonds, N.W. Genotype (G), environment (E) and GE components of crop yields. Exp. Agric. 1981, 17, 355-362. [CrossRef]

90. Araus, J.L.; Slafer, G.A.; Royo, C.; Serret, M.D. Breeding for yield potential and stress adaptation in cereals. Crit. Rev. Plant Sci. 2008, 27, 377-412. [CrossRef]

91. Varshney, R.K.; Thudi, M.; Pandey, M.K.; Tardieu, F.; Ojiewo, C.; Vadez, V.; Whitbread, A.M.; Siddique, K.H.M.; Nguyen, H.T.; Carberry, P.S.; et al. Accelerating genetic gains in legumes for the development of prosperous smallholder agriculture: Integrating genomics, phenotyping, systems modelling and agronomy. J. Exp. Bot. 2018, 69, 3293-3312. [CrossRef]

92. Watson, A.; Ghosh, S.; Williams, M.J.; Cuddy, W.S.; Simmonds, J.; Rey, M.-D.; Md Hatta, M.A.; Hinchliffe, A.; Steed, A.; Reynolds, D.; et al. Speed breeding is a powerful tool to accelerate crop research and breeding. Nat. Plant. 2018, 4, 23-29. [CrossRef]

93. Varshney, R.K.; Song, C.; Saxena, R.K.; Azam, S.; Yu, S.; Sharpe, A.; Cannon, S.; Baek, J.; Rosen, B.D.; Taran, B.; et al. Draft genome sequence of chickpea (Cicer arietinum) provides a resource for trait improvement. Nat. Biotechnol. 2013, 31, 240-246. [CrossRef]

94. Deokar, A.; Sagi, M.; Tar'an, B. Genome-wide SNP discovery for development of high-density genetic map and QTL mapping of ascochyta blight resistance in chickpea (Cicer arietinum L.). Theor. Appl. Genet. 2019, 132, 1861-1872. [CrossRef]

95. Paul, P.J.; Samineni, S.; Thudi, M.; Sajja, S.B.; Rathore, A.; Das, R.R.; Khan, A.W.; Chaturvedi, S.K.; Lavanya, G.R.; Varshney, R.K.; et al. Molecular mapping of QTLs for heat tolerance in chickpea. Int. J. Mol. Sci. 2018, 19, 2166. [CrossRef] [PubMed]

96. Verma, S.; Gupta, S.; Bandhiwal, N.; Kumar, T.; Bharadwaj, C.; Bhatia, S. High-density linkage map construction and mapping of seed trait QTLs in chickpea (Cicer arietinum L.) using Genotyping-by-Sequencing (GBS). Sci. Rep. 2015, 5, 17512. [CrossRef]

97. von Wettberg, E.J.B.; Chang, P.L.; Başdemir, F.; Carrasquila-Garcia, N.; Korbu, L.; Moenga, S.M.; Bedada, G.; Greenlon, A.; Moriuchi, K.S.; Singh, V.; et al. Ecology and genomics of an important crop wild relative as a prelude to agricultural innovation. Nat. Commun. 2018, 9, 649. [CrossRef]

98. Cacho, O.J.; Moss, J.; Thornton, P.K.; Herrero, M.; Henderson, B.; Bodirsky, B.L.; Humpenöder, F.; Popp, A.; Lipper, L. The value of climate-resilient seeds for smallholder adaptation in sub-Saharan Africa. Clim. Chang. 2020, 1-17. [CrossRef]

99. Tomar, B.S.; Kalyanrao, R.; Kumar, K.V. Seed production: An entrepreneurial venture. Indian Farming 2011, 61,4-9.

100. Sisay, D.T.; Verhees, F.J.H.M.; van Trijp, H.C.M. Seed producer cooperatives in the Ethiopian seed sector and their role in seed supply improvement: A Review. J. Crop. Improv. 2017, 31, 323-355. [CrossRef]

101. Sperling, L.; Gallagher, P.; McGuire, S.; March, J.; Templer, N. Informal Seed Traders: The Backbone of Seed Business and African Smallholder Seed Supply. Sustainability 2020, 12, 7074. [CrossRef]

102. Bishaw, Z.; van Gastel, A.J.; Gregg, B.R. Sustainable Seed Production of Cool Season Food Legumes in CWANA Region. In Proceedings of the Fourth International Food Legumes Research Conference (IFLRC-IV), New Delhi, India, 18-22 October 2005; Kharkwal, M.C., Ed.; ISGPB: New Delhi, India, 2008; pp. 231-257.

103. Ojiewo, C.O.; Omoigui, L.O.; Janila, P.; Lenné, J.M. Grain legume seed systems for smallholder farmers: Perspectives on successful innovations. Outlook Agric. 2020, 1-7. [CrossRef]

104. McGuire, S.; Louise, S. Making seed systems more resilient to stress. Glob. Environ. Chang. 2013, 23, 644-653. [CrossRef] 
105. Dhehibi, B.; Rudiger, U.; Moyo, H.P.; Dhraief, M.Z. Agricultural Technology Transfer Preferences of Smallholder Farmers in Tunisia's Arid Regions. Sustainability 2020, 12, 421. [CrossRef]

106. Kaur, K.; Kaur, P. Agricultural Extension Approaches to Enhance the Knowledge of Farmers. Int. J. Curr. Microb. Appl. Sci. 2018, 7, 2367-2376. [CrossRef]

107. Campenhout, B.V.; Spielman, D.J.; Lecoutere, E. Information and communication technologies to provide agricultural advice to smallholder farmers: Experimental evidence from Uganda. Am. J. Agric. Econ. 2020, 1-21. [CrossRef]

Publisher's Note: MDPI stays neutral with regard to jurisdictional claims in published maps and institutional affiliations.

(C) 2020 by the authors. Licensee MDPI, Basel, Switzerland. This article is an open access article distributed under the terms and conditions of the Creative Commons Attribution (CC BY) license (http://creativecommons.org/licenses/by/4.0/). 